Session 3125

\title{
Integration of design in the engineering core: Teaching engineering science courses with design in mind.
}

\author{
Josué Njock Libii \\ Engineering Department \\ Indiana University-Purdue University \\ Fort Wayne, Indiana 46805-1499 USA
}

For more than twelve years, design has been successfully integrated into two, erstwhile, lecture courses in the ME curriculum of Indiana University Purdue University Fort Wayne. The courses are Fluid Mechanics (a required course) and Vibration Analysis (a technical elective). This concept is part of an educational philosophy that distributes design experience across the curriculum before it culminates into two capstone-design courses in the senior year. This success has led the author to change the way he teaches engineering science courses.

In this paper, the author synthesizes the experiences and success that he has had in integrating design in fluid mechanics (Njock Libii, 2002) ${ }^{25}$ and in vibration analysis into the essential pedagogical practices that led to this success.

There has been renewed interest in examining the teaching of design in the engineering curriculum in the past decade (Martin, Adams, \&Turns, 2002) ${ }^{21}$. This interest has been spurred in part by the new accreditation criteria required by ABET-2000 and in part by critical reviews of undergraduate curricula in engineering (Njock Libii, 2002) ${ }^{25}$ A review of the literature has revealed that more than 850 papers were published on design from 1990 through 2002. Approximately $60 \%$ of these papers are concentrated on teaching engineering design. The contents of these papers fall into five categories: design experiences in first-year courses; focuseddesign courses; integrating design in the engineering core; capstone design courses; and general discussion of issues related to teaching engineering design.

\section{Categories}

The categories into which the papers that were surveyed fall are defined and discussed briefly below; representative samples of papers from each category are referenced in the discussion as

AProceedings of the 2003 American Society for Engineering Education Annual Conference \& Exposition Copyright (C) 2003, American Society for Engineering 
well.

A. Design experiences in first-year courses. Design courses in this category have three main goals: to introduce the concept of design; to give hands-on experiences in design early in the undergraduate careers of students; and to motivate students to study engineering, thereby, enhancing their retention and persistence in that major. A sample of references to papers that illustrate these ideas is: Richards \& Carlson-Skalak (1997) ${ }^{32}$; Hall (1998) $)^{14}$; Zhang (1999) Ghosh (2000) ${ }^{13}$; and (Njock Libii, 2002) ${ }^{25}$.

B. Focused-design courses. These kinds of courses are specifically dedicated to teaching design. However, their goal is focused on teaching design techniques that are specific to a given topic or a narrow subject. Typically, they are offered after the freshman year; but they tend to be found during the third and fourth years. Examples of such courses are: design of mechanisms (ME), design of experiments (IE, ME, EE), design of filters (EE), electronics design (EE), design of structures(CE), design of hydraulic systems (CE), design of software (EE, CompE, Software Engr.), chemical processing (ChemE), mechatronics(ME). A sample of references to papers that illustrate these ideas is shown below: Cairns \& Chrisp (1996) ${ }^{5}$; Durfee (1995) ${ }^{9}$; Garimella $(1999)^{11}$; Gerhard (1999) ${ }^{12}$; Lightner et al (2000) $)^{17}$; Tullis (2001) ${ }^{39}$; Dunn-Rankin, Bobrow, Mease \& McCarthy $(1998)^{8}$; (Smith, 1998) ${ }^{37}$; Bhadeshia (1995) ${ }^{4}$; and Seville $(2000)^{36}$.

C. Integrating design in the engineering core. The goal in this category is to integrate design into core courses that are not dedicated to design. Sample references in this category are shown here. Gosh (2000) ${ }^{13}$ describes a seven-year experience with integrating design into undergraduate honors theses at Brown University, Njock Libii (2002) ${ }^{25}$ describes a ten-year experience with integrating design in the first course in fluid mechanics; Lissenden, Salamon and Wagle ( 2002 $)^{18}$ discuss design projects in advanced mechanics of materials; Atherton (1998) ${ }^{1}$ discusses controls; Schilling \& Hagen (2000) ${ }^{34}$, sanitary engineering; Lightner, Carlson, Sullivan, Brandenmuehl \& Reitsma (2000) ${ }^{17}$, the concept of a living laboratory in Colorado; and Westerberg \& Subrahmanian $(2000)^{43}$, product design.

D. Senior year: Capstone Design courses: These courses are offered toward the end of the undergraduate career of students to allow them to integrate what they have learned. Typically, they solve a practical problem that is both substantial and relevant. Capstone design courses are taught in a wide variety of approaches. Two sample references to capstone designs are: a case study in which senior designs were supervised and evaluated by practicing engineers at the university of Oklahoma (Knox, Sabatini, Hughes, Lambert, \& Ketner, 1998) ${ }^{16}$; and Capstone design courses in the Civil Engineering department at the university of Missouri-Rolla taught by faculty with extensive experience in both teaching and in engineering practice (Morris \& LaBoube, 1995$)^{23}$.

E. General issues and principles in, and approaches to, teaching engineering design. Sample references in this group are: Computation in design (Vanderplaas, 1993) ${ }^{40}$; a discovery approach

\section{AProceedings of the 2003 American Society for Engineering Education Annual Conference \& Exposition Copyright (C) 2003, American Society for Engineering Education@}


to teaching design (Parcover \& McCuen, 1995) ${ }^{28}$; hands-on, practical approaches to teaching design (Miri and $\mathrm{Fu}, 1993)^{22}$; learning design by reading a textbook about it(Atman \& Bursic, 1996) ${ }^{2}$; creative problem solving in design (Mackinzie, Allen, Earl \& Gilmour, 1999) ${ }^{20}$; using behavior modification to teach design (Gerhard ,1999) ${ }^{12}$; Donald Schon's philosophy of design education (Waks, 2001) ${ }^{41}$; education in new product design (Cardozo et al , 2002) ${ }^{6}$; teaching engineering design (Walter, 2002) ${ }^{42}$, multidisciplinary product development (Srinivasan \& Lovejoy 2002) ) $^{38}$, and problem solving in design (O’Shea, 2002) ${ }^{26}$.

To the author's best knowledge, the literature does not appear to suggest step-by-step procedures to be followed by engineering educators who want to integrate new design experiences into existing core courses. In the remainder of this paper, we present a synthesis of our experience with integrating design in existing core courses in the form of steps to be followed in doing so. These steps are consistent with what other writers have reported about teaching engineering

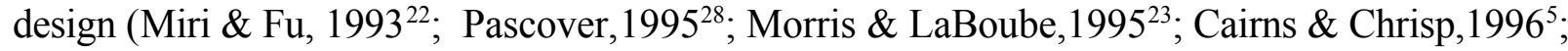
Ribando \& O’Leary, 1998 ${ }^{31}$; Zhang, 1999 ${ }^{45}$; Dunn-Rankin, $1998^{8}$; and Walter, 2002) ${ }^{42}$.

\section{Pedagogical Practices}

Upon reflecting on our success and reading the literature on teaching design, it was determined that seven practices were responsible for this success. They relate to course structure and philosophy, course assignments, and the conduct of the course itself (Bhadeshia, 1995 ${ }^{4}$; Smith, 1998 ${ }^{37}$; Hall, $1998^{14}$; Gerhard, 1999 ${ }^{12}$; Ghosh, 2000 ${ }^{13}$; Tullis, 2001 ${ }^{39}$; Srinivasan \& Lovejoy $\left.2002^{38}\right)$. The detailed manners in which these were done are discussed below.

\section{A. Course structure and philosophy had to be reconsidered and revised in two ways.}

1-The structure of the course had to be reconsidered and modified in two ways:

Some material had to be eliminated from the course in order to make room for hands-on activities that are necessary for learning design.

2- It became necessary to change the philosophy of the course from one of teaching engineering science for its own sake to that of teaching engineering science for the sake of learning to apply its results to solve practical problems and to create products that work.

\section{B. Course assignments were reconstituted in two ways.}

1- Assignments were studied to identify the specific role that each played in helping achieve course objectives. They were then grouped into five categories: definitions and drills, comprehension, integration, applications, and design, respectively. The role of each group of assignments was explained to students.

2- Design assignments consisted of several open-ended problems from which students had to choose and they were assigned very early in the semester. The problems were stated in simple terms; they were related to the material being learned in an explicit manner; and each involved 
hands-on activities. Progress reports were required on a periodic basis.

C. Conduct of the course was changed in three ways.

1- Integrate all course work carefully to help students see it as a coherent whole. Encourage students to actually do the assigned reading. Proofs of basic results presented in the textbook were not reproduced in class. Students were required to read them on their own. Class time was then spent on: a) highlighting basic concepts and results found in the reading assignment; b) relating them to each other; c) demonstrating their use in problem solving; and d) discussing their application to engineering design and scientific work.

2- Feedback on submitted work must be rapid and useful; it must also provide incentives to learn. Progress reports were collected, graded, and returned to students quickly. Feedback comments had to be specific, clear, unambiguous, and encouraging. Partial credit was administered to reward progress made toward achieving course objectives.

3- Students were strongly encouraged to work in small groups in order to enhance collaborative learning, stimulate peer teaching, and cultivate effective skills in communication.

\section{Conclusion.}

There appear to be different ways to approach the teaching of design and, at present, however, there is no agreement among authors regarding how to teach engineering design. But the increasingly large literature on teaching design is making it possible to begin to see common elements among the different ways of teaching this subject. Although there is not a consensus yet on how to teach design, a central element that helps one succeed in this endeavor is emerging, nevertheless. In teaching design, theory and analysis cease to be ends in themselves. Instead, they become means to assist students in learning how to solve practical problems and make products that work.

In order to integrate design into an existing core course, the author's experience shows that changes must occur in four aspects of the course: course philosophy, course structure, course assignments, and the conduct of the course. This paper explains how this transformation process was achieved with success in two engineering science courses: fluid mechanics and vibration analysis. It also cites many references that demonstrate that teaching design involves course transformation and innovation.

\section{References.}

1. Atherton, D.P.(Univ of Sussex), Teaching classical design using the control kit Measurement \& Control, 31, 5, Jul, 1998, p 143-146. Inst of Measurement \& Control 
2. Atman, Cynthia J.(Univ of Pittsburgh); Bursic, Karen M. ,Teaching engineering design: can reading a textbook make a difference? Research in Engineering Design - Theory, Applications, and Concurrent Engineering, 8, 4, 1996, p 240-250, Springer-Verlag GmbH \& Company $\mathrm{KG}$, Germany

3. Basu, Arun J. (Imperial Coll. of Sci., Technol.), Ganquli, Raiive; Sturgul, John R., Technology implementation in learning and teaching (tilt) Mineral Resources Engineering, v 11, n 1, January/March , 2002, p 129-135.

4. Bhadeshia, Harry (Univ of Cambridge), Transparent steel: the teaching of creative design Materials World, 3, 3, Mar, 1995, p 128-130.

5. Cairns, J.; Chrisp, T.M., Strategy for teaching structural engineering design, Structural Engineer, 74, 22, Nov 19, 1996, p 375.

6. Cardozo, Richard N.(Carlson School of Management, Institute of Technology, University of Minnesota); Durfee, William K.; Ardichvili, Alexander; Adams, Carl; Erdman, Arthur G.; Hoey, Michael; laizzo, Paul A.; Mallick, Debashish N.; Bar-Cohen, Avi; Beachy, Robert; Johnson, Alec, Perspective: Experiential education in new product design and business development, Journal of Product Innovation Management, $\mathrm{v}$ 19, n 1, January, 2002, p 4-17, Elsevier Science Inc.

7. Davies, Chris H.J.(School of Physics and Materials Eng., Monash University), Student engagement with simulations: A case study, Computers and Education, v 39, n 3, November 2002, 2002, p 271-282, Elsevier Science Ltd.

8. Dunn-Rankin, Derek(Univ of California); Bobrow, James E.; Mease, Kenneth D.; McCarthy, J. Michael Engineering design in industry: Teaching students and faculty to apply engineering science in design, Journal of Engineering Education, 87, 3, July, 1998, p 219-222.

9. Durfee, William K.(Univ of Minnesota), Designing smart machines: teaching mechatronics to mechanical engineers through a project-based, creative design course, Mechatronics, 5, 7, Oct, 1995, p 775-785, Pergamon Press Ltd, Engl

10. Sven Esche, Hamid Hadim, (Stevens Institute of Technology) Introduction of project based learning into mechanical engineering courses, Session 2366- Design in the Engineering Core, 2002 ASEE Annual Conference and Exposition, June 16-19, 2002.

11. Garimella, Srinivas (Iowa State Univ.), Teaching the design of thermal systems using equation solvers, ASHRAE Transactions, 105, pt 1, 1999, p 902-911, Proceedings of the 1999 ASHRAE Winter Meeting, Jan 23-Jan 27 1999, Chicago, IL, USA.

AProceedings of the 2003 American Society for Engineering Education Annual Conference \& Exposition Copyright () 2003, American Society for Engineering Education@ 
12. Gerhard, Glen C.(Univ of Arizona), Teaching design with behavior modification techniques in a pseudocorporate environment, IEEE Transactions on Education, 42, 4, Nov, 1999, p 255-260, Institute of Electrical and Electronics Engineers Inc., USA.

13. Ghosh, Sumit(Arizona State Univ.), Integrating design into undergraduate honors theses in a computer engineering program: An experiment, IEEE Transactions on Education, 43, 2, May, 2000, p. 203-210, Institute of Electrical and Electronics Engineers Inc.

14. Hall, D.V.(Portland State Univ), Teaching design methodology and 'industrial strength' EDA tools in a first-term freshman digital logic course, IEEE Transactions on Education, 41, 1, Feb, 1998, p 45-49.

15. Hein, Teresa L.(American Univ); Budny, Dan D., Teaching to students' learning styles: approaches that work, Proceedings - Frontiers in Education Conference, 2, 1999, p 12c1-7 - 12c1-14, 29th Annual Frontiers in Education Conference: 'Designing the Future of Science and Engineering Education', Nov 10-Nov 13 1999, San Juan, Puerto, Institute of Electrical and Electronics Engineers Inc., USA.

16. Knox, Robert C.(Univ of Oklahoma); Sabatini, David A.; Hughes, David E.; Lambert, Robert; Ketner, Russ, Teaching engineering design with practitioner supervision: A case study, Journal of Professional Issues in Engineering Education and Practice, 124, 4, Oct, 1998, p 105-109.

17. Lightner, Michael R.(Univ of Colorado); Carlson, Lawrence; Sullivan, Jacquelyn F.; Brandemuehl, Michael J; Reitsma, Rene, Living laboratory, Proceedings of the IEEE, 88, 1, Jan, 2000, p 31-40.

18. Cliff Lissenden, Nick Salamon, Gautam Wagle (Penn State), Design projects for advanced mechanics of materials, Session 2468- Improving Mechanics of Materials Classes, 2002 ASEE Annual Conference and Exposition, June 16-19, 2002.

19. Thomas Litzinger, Stefani Bjoklund, Sangha Lee, John Wise (Penn State), From intellectual development to expertise, Session 2430- Learning styles, 2002 ASEE Annual Conference and Exposition, June 16-19, 2002.

20. Mackenzie, J.G.; Allen, R.M.; Earl, W.B.; Gilmour, I.A., Teaching creative problem-solving skills in engineering design, Chemical Engineering Education, 33, 2, Spring, 1999, p 150-153, 157.

21. Joshua Martin, Robin Adams, Jennifer Turns (Univ.of Washington) Who listens to whom? A citations analysis of recent papers on engineering design education, Session2325-Innovation in Design Education, 2002 ASEE Annual Conference and Exposition, June 16-19, 2002.

22. Miri, S.M.(Univ. of North Carolina); Fu, R.J., Hands-on practical approach to teaching engineering design, IEEE Transactions on Education, v 36, n 1, Feb, 1993, p 131-136.

AProceedings of the 2003 American Society for Engineering Education Annual Conference \& Exposition Copyright () 2003, American Society for Engineering Education@ 
23. Morris, C.D. and LaBoube, R.A. Teaching civil engineering design: Observations and experiences, Journal of Professional Issues in Engineering Education and Practice,121, 1, Jan,1995, p 47-53.

24. Morrison, S.J. ,The missing link, Engineering Science and Education Journal, v 11, n 4, August 2002, 2002, p 133-138, Institution of Electrical Engineers.

25. Josué Njock Libii, Integration of Design in the first course in fluid mechanics: experience and evaluation, Session 2366- Design in the Engineering Core, 2002 ASEE Annual Conference and Exposition, June 16-19, 2002.

26. O'Shea, Donald C., Problem solving, Optical Engineering, v. 41, n 7, July 2002, 2002, p 14621463, The International Society for Optical Engineering.

27. Mark Palmer (Kettering Univ.), Incorporating design into introductory statics and strength of materials courses. Session 2366- Design in the Engineering Core, 2002 ASEE Annual Conference and Exposition, June 16-19, 2002.

28. Parcover, Jason A.(Univ of Maryland at Coll. Park); McCuen, Richard H., Discovery approach to teaching engineering design, Journal of Professional Issues in Engineering Education and Practice, 121, 4, Oct, 1995, p 236-241.

29. Philip Parker (Univ. Wisconsin-Platteville) Cognitive style and learning preferences in Engineering Undergraduates, Session 2430- Learning styles, 2002 ASEE Annual Conference and Exposition, June 16-19, 2002.

30. Parkinson, B.(Dept. of Design Technol. and Mgmt., University of Hertfordshire); Hudson, P. Extending the learning experience using the Web and a knowledge-based virtual environment, Computers and Education, v 38, n 1-3, January/April 2002, p 95-102, Elsevier Science Ltd.

31. Ribando, Robert J.(Univ of Virginia); O'Leary, Gerald W., Teaching module for one-dimensional, transient conduction, Computer Applications in Engineering Education, 6, 1, 1998, p 41-51. John Wiley \& Sons Inc, USA

32. Richards, Larry G.(Univ of Virginia); Carlson-Skalak, Susan, Faculty reactions to teaching engineering design to first year students, Journal of Engineering Education, 86, 3, July, 1997, p 233-240.

33. Jaspal Sandhu, Eberhard Bamberg (MIT), Active engagement pedagogy for an introductory solid mechanics course, Session 2468- Improving Mechanics of Materials Classes, 2002 ASEE Annual Conference and Exposition, June 16-19, 2002.

34. Schilling, W.(Norwegian Univ of Science and Technology); Hagen, E. , Project-based learning in

AProceedings of the 2003 American Society for Engineering Education Annual Conference \& Exposition Copyright () 2003, American Society for Engineering Education@ 
sanitary engineering-preliminary conclusion after three year's experience, Water Science and Technology, 41, 2, 2000, p 75-81.

35. Schmidt, Janet(Univ of Maryland at College Park); Yang, Chia-Hung; Wilson, Otto; Zhang, Guangming, Assessment of the teaching-learning effectiveness of a freshman design course, Proceedings Frontiers in Education Conference, 3, 1999, p 13b1-1 - 13b1-6., 29th Annual Frontiers in Education Conference: 'Designing the Future of Science and Engineering Education', Nov 10-Nov 13 1999, San Juan, Puerto Rico, Institute of Electrical and Electronics Engineers Inc., USA.

36. Seville, Jonathan, Teaching chemical product engineering, Chemical Engineer (London), 709, Sep, 2000, p 18-19, Institute of Chemical Engineers.

37. Smith, R.P.(Univ. of Washington) Teaching design for assembly using product disassembly, IEEE Transactions on Education, 41, 1, Feb, 1998, p 50-53.

38. Srinivasan, V.(Graduate School of Business, Stanford University); Lovejoy, William S., Perspective: Ten years of experience teaching a multi-disciplinary product development course, Journal of Product Innovation Management, v 19, n 1, January, 2002, p 32-45, Elsevier Science Inc.

39. Tullis, B.P.(Utah Water Research Laboratory, Utah State University); Tullis, J.P., Real-world projects reinforce fundamentals in the classroom Journal of Hydraulic Engineering, v 127, n 12, December 2001, 2001, p 992-995. American Society of Civil Engineers.

40. Vanderplaas, Garret N.(VMA Engineering), Teaching design through computation, IEEE Transactions on Education, v 36, n 1, Feb, 1993, p 110-112.

41. Waks, Leonard J.(Temple Univ) Donald Schon's philosophy of design and design education, International Journal of Technology and Design Education, 11, 1, 2001, p 37-51, Kluwer Academic Publishers, Netherlands

42. Walter, Patrick L., Editorial: Teaching engineering design - One university's program $S$ V Sound and Vibration, v 36, n 8, August 2002, 2002, p.5-6, Acoustical Publications Inc.

43. Westerberg, Arthur W. (Inst. for Complex Engineered Systems); Subrahmanian, Eswaran, Product design, Computers and Chemical Engineering, 24, 2, Jul, 2000, p 959-966

The International Symposium on Process Systems Engineering, Jul 16-Jul 21 2000, Keystone, CO .

44. Wilson, Jack M.(Rensselaer Polytechnic Inst); Jennings, William C., Studio courses: how information technology is changing the way we teach, on campus and off, Proceedings of the IEEE, 88, 1, Jan, 2000, p 72-80, Institute of Electrical and Electronics Engineers Inc., USA.

AProceedings of the 2003 American Society for Engineering Education Annual Conference \& Exposition Copyright () 2003, American Society for Engineering Education@ 
45. Zhang, Guangming (Univ of Maryland at College Park), Support structure of teaching engineering design to freshman students, Proceedings - Frontiers in Education Conference, 1, 1999, p 12a6-112a6-6, 29 ${ }^{\text {th }}$ Annual Frontiers in Education Conference: 'Designing the Future of Science and Engineering Education', Nov 10-Nov 13 1999, San Juan, Puerto Rico, Institute of Electrical and Electronics Engineers Inc., USA.

\footnotetext{
JOSUÉ NJOCK LIBII

Josué Njock Libii is Associate Professor of Mechanical Engineering at Indiana UniversityPurdue University, Fort Wayne, Indiana. He earned a B.S.E in Civil Engineering, an M.S.E. in Engineering Mechanics, and a Ph.D. in Engineering Mechanics from the University of Michigan, Ann Arbor, Michigan. His areas of interest are Engineering Education, particularly, Mechanics and its application and use in related fields.
} 
AProceedings of the 2003 American Society for Engineering Education Annual Conference \& Exposition Copyright (C) 2003, American Society for Engineering Education@ 